\title{
Short Communication \\ Paediatric germ cell tumours and congenital abnormalities: a Children's Oncology Group study
}

\author{
KJ Johnson', JA Ross*, ${ }^{*, 2}$, JN Poynter ${ }^{1,2}$, AM Linabery', LL Robison ${ }^{3}$ and XO Shu ${ }^{4}$ \\ 'Division of Epidemiology and Clinical Research, Department of Pediatrics, University of Minnesota, Minneapolis, MN 55455, USA; ${ }^{2}$ Masonic Cancer \\ Center, University of Minnesota, Minneapolis, MN 55455, USA; ${ }^{3}$ Department of Epidemiology and Cancer Control, St Jude Children's Research Hospital, \\ Memphis, TN 37232, USA; ${ }^{4}$ Department of Medicine, Vanderbilt Ingram-Cancer Center and Center for Health Services Research, Vanderbilt University, \\ Nashville, TN 38105, USA
}

METHODS: Maternally reported congenital abnormalities (CAs) were examined in a case-control study of 278 cases of paediatric germ cell tumours (GCTs) and 423 controls.

RESULTS AND CONCLUSIONS: Germ cell tumours were significantly associated with cryptorchidism in males $(\mathrm{OR}=10.8,95 \% \mathrm{Cl}$ : $2.1-$ 55. I), but not with any other specific CA in either sex.

British Journal of Cancer (2009) I 0 I, 518-52I. doi:I0.1038/sj.bjc.6605 I69 www.bjcancer.com

Published online 14 July 2009

(c) 2009 Cancer Research UK

Keywords: germ cell tumours; paediatrics; congenital abnormalities

The risk factors for paediatric germ cell tumours (GCTs), which comprise a histologically heterogeneous group of tumours affecting an estimated 360 individuals $<15$ years of age each year in the United States (Bernstein et al, 1999; US Census Bureau, 2007), have not been well described (Bernstein et al, 1999). However, congenital abnormalities (CAs) have often been reported in association with GCTs in case series and in record linkage studies (Li and Fraumeni, 1972; Fraumeni et al, 1973; Li et al, 1973; Birch et al, 1982; Mann et al, 1993; Altmann et al, 1998; Little, 1999; Nishi et al, 2000; Merks et al, 2005; Bjorge et al, 2008; Rankin et al, 2008). The presence of cryptorchidism is a confirmed risk factor for testicular GCTs in men (Sarma et al, 2006), but its association with paediatric GCTs has not been as well studied. We evaluated the association between certain CAs and childhood GCTs by sex, age at diagnosis, anatomical location, and histology in a Children's Oncology Group (COG) study.

\section{MATERIALS AND METHODS}

The study protocol was approved by the Institutional Review Boards of the University of Minnesota and by the participating COG institutions. Details regarding this study have been described previously (Chen et al, 2005). Briefly, GCT cases with malignant extracranial tumours, diagnosed from the time of birth to 14 years of age between 1 January 1993 and 31 December 2001, were ascertained from US and Canadian COG hospitals. Eligible diagnoses were dysgerminoma-seminoma-germinoma, embryonal carcinoma, yolk sac tumour, choriocarcinoma, malignant

*Correspondence: Dr JA Ross, Division of Pediatric Epidemiology and Clinical Research, Department of Pediatrics, Children's Cancer Research Fund Chair in Molecular Epidemiology, MMC 422, 420 Delaware St. S.E., Minneapolis, MN 55455, USA; E-mail: rossx014@umn.edu

Received 27 April 2009; revised 4 June 2009; accepted 8 June 2009; published online 14 July 2009 teratoma, and mixed GCTs. Controls were recruited through random digit dialling, and frequency was matched to cases on sex and birth year \pm 1 year, at ratios of approximately $1: 2$ for males and $1: 1$ for females. Cases and controls were eligible if they had a telephone in their residence and if their biological mother spoke English and consented to an interview. Participation rates were 81 and $67 \%$ for cases and controls, respectively. Exposure information was collected from mothers by telephone interview, including the seven CA categories shown in Table 3.

\section{Statistical analyses}

We used SAS version 9.1. (SAS Institute Inc., Cary, NC, USA) to conduct statistical analyses. Statistical differences in the frequency or means of sociodemographic and infant characteristics between cases and controls were assessed using Mantel-Haenszel $\chi^{2}$ tests and one-way analysis of variance. We used unconditional logistic regression to examine the associations between CAs and GCTs, adjusting for the matching factors, sex and child's age. We conducted analyses stratified by sex, age at diagnosis $(\leqslant 2,>2$ years), tumour histology, and anatomical location. As the number of cases was small, the effect of potential confounding variables on risk estimates was examined by adding them one at a time to models. All statistical tests were two-sided.

\section{RESULTS}

In both sexes, GCTs occurred most frequently in the gonads, with yolk sac tumours being the most common histological subtype, followed by other non-seminomas in males and teratomas in females. The distribution of age at diagnosis was bimodal, with peaks observed before the age of 5 years and after the age of 10 years in both sexes (Table 1).

No statistical differences were found between cases and controls with respect to gestational age, birth weight, or maternal age. 
Table I Characteristics of paediatric GCT diagnoses

\begin{tabular}{lcc}
\hline Tumour characteristics & $\begin{array}{c}\text { No. of males } \\
\text { (\%) }\end{array}$ & $\begin{array}{c}\text { No. of females } \\
\text { (\%) }\end{array}$ \\
\hline Anatomical location & & \\
Testis/ovary & $47(56.6)$ & $97(49.7)$ \\
Extragonadal & $31(37.4)$ & $89(45.6)$ \\
Metastatic & $3(3.6)$ & $4(2.1)$ \\
Unknown & $2(2.4)$ & $5(2.6)$ \\
Histology & & \\
Yolk sac tumour & $46(55.4)$ & $79(40.5)$ \\
Teratoma & $14(16.9)$ & $57(29.2)$ \\
Seminoma & $2(2.4)$ & $43(22.1)$ \\
Other non-seminomas & $8(4.1)$ \\
Other & $17(20.5)$ & $7(3.6)$ \\
Not specified & $3(3.6)$ & $1(0.51)$ \\
Diagnosis age category (years) & $1(1.2)$ & $84(43.1)$ \\
0-4 & & $37(19.0)$ \\
5-9 & $64(77.1)$ & $74(38.0)$ \\
I0-14 & $4(4.8)$ & $195(100.0)$ \\
\hline Total & $15(18.1)$ & \\
\hline GCT & $83(100.0)$ &
\end{tabular}

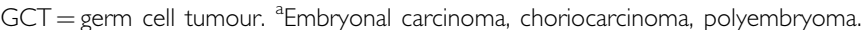
bMixed germ cell tumour components and malignant tumour cells.

Table 2 Infant and parental sociodemographic characteristics of cases and controls

\begin{tabular}{|c|c|c|c|}
\hline Characteristics & $\begin{array}{l}\text { No. of } \\
\text { cases (\%) }\end{array}$ & $\begin{array}{c}\text { No. of } \\
\text { controls (\%) }\end{array}$ & $P$-value \\
\hline \multicolumn{4}{|c|}{ Gestational age category (weeks) } \\
\hline$<37$ & $35(12.6)$ & $44(10.4)$ & \\
\hline $37-42$ & $236(84.9)$ & $367(86.8)$ & \\
\hline$>42$ & $7(2.5)$ & $12(2.8)$ & 0.37 \\
\hline Mean (s.d.) & $39.5(5.6)$ & $39.6(4.6)$ & 0.76 \\
\hline \multicolumn{4}{|l|}{ Birth weight (grams) } \\
\hline $2501-4000$ & $214(77.0)$ & $35 \mid(83.0)$ & \\
\hline$\leqslant 2500$ & $22(7.9)$ & $26(6.1)$ & \\
\hline$>4000$ & $42(15.1)$ & $46(10.9)$ & 0.05 \\
\hline Mean (s.d.) & $3354(68 \mathrm{I})$ & $3373.7(590)$ & 0.69 \\
\hline \multicolumn{4}{|c|}{ Maternal age category (years) } \\
\hline$\leqslant 24$ & $90(32.4)$ & $128(30.3)$ & \\
\hline $25-29$ & $99(35.6)$ & $145(34.3)$ & \\
\hline $30-34$ & $60(21.6)$ & III (26.2) & \\
\hline$\geqslant 35$ & $29(10.4)$ & $39(9.2)$ & 0.56 \\
\hline Mean (s.d.) & $27.2(5.5)$ & $27.3(5.4)$ & 0.66 \\
\hline \multicolumn{4}{|l|}{ Maternal education } \\
\hline Less than high school & $28(10.1)$ & $23(5.4)$ & \\
\hline High school graduate & $110(39.7)$ & $143(33.9)$ & \\
\hline College, no degree & $53(19.1)$ & $97(23.0)$ & \\
\hline $\begin{array}{l}\text { College degree and/or } \\
\text { graduate school }\end{array}$ & $86(31.1)$ & $159(37.7)$ & 0.004 \\
\hline \multicolumn{4}{|l|}{ Maternal race } \\
\hline White & $213(76.9)$ & $356(84.4)$ & \\
\hline Black & $25(9.0)$ & $25(5.9)$ & \\
\hline Hispanic & $27(9.8)$ & $23(5.4)$ & \\
\hline Other & $12(4.3)$ & $18(4.3)$ & 0.05 \\
\hline \multicolumn{4}{|c|}{ Household income (US dollars) } \\
\hline$<20000$ & $85(31.0)$ & $83(19.9)$ & \\
\hline $20000-30000$ & $60(21.9)$ & $109(26.1)$ & \\
\hline $30001-50000$ & $63(23.0)$ & $124(29.7)$ & \\
\hline$>50000$ & $66(24.1)$ & $102(24.4)$ & 0.03 \\
\hline
\end{tabular}

Control mothers were more educated and more likely to be of white race than were case mothers. A higher frequency of cases had household incomes below $\$ 20000$ than did controls (Table 2).

In males, there were statistically significant increased risks of GCTs in association with any CA $(\mathrm{OR}=2.5,95 \% \mathrm{CI}$ : $1.3-4.9)$, which was mainly because of cryptorchidism $(\mathrm{OR}=10.8,95 \% \mathrm{CI}$ : 2.1 -55.1). The risk of GCTs increased significantly with increasing number of CAs in males $(P$ for trend $=0.01)$. There were no other significant associations between GCTs and CAs in either sex (Table 3). Models that included the variables shown in Table 2 did not materially change the results (data not shown).

There were no significant associations between CAs and GCTs in children $\leqslant 2$ or $>2$ years, except for cryptorchidism, in which risks were similar $\left(\mathrm{OR}_{\leqslant 2}\right.$ years $=8.2,95 \% \mathrm{CI}: 0.9-72.7 ; \mathrm{OR}_{>2}$ years $=14.6,95 \%$ CI: $1.4-152.2$ ) (data not shown).

Individuals with any $\mathrm{CA}$ had a significantly increased risk for extragonadal GCTs $(\mathrm{OR}=1.7,95 \% \mathrm{CI}: 1.0-2.9)$, with a significantly positive linear trend with increasing number of CAs $(P=0.009) \quad$ (Supplementary Table 1$)$. Statistically significant increased risks were observed for GCTs in association with cryptorchidism for gonadal $(\mathrm{OR}=19.9,95 \% \mathrm{CI}$ : 3.5-111.9) but not for extragonadal $(\mathrm{OR}=3.0,95 \% \mathrm{CI}: 0.3-34.7)$ GCTs. For extragonadal GCTs, significant increased risks were found in association with mental retardation $(\mathrm{OR}=15.8,95 \% \mathrm{CI}$ : $1.4-$ 178.0), congenital heart defects $(\mathrm{OR}=2.7,95 \% \mathrm{CI}: 1.1-6.0)$, and skeletal defects $(\mathrm{OR}=5.0,95 \%$ CI: $1.3-19.1)$. No significant associations were observed between GCTs and CAs in analyses stratified by histological subtype (seminoma, yolk sac tumour, teratoma, and other non-seminomas), with the exception of cryptorchidism, which increased the risk for seminomas $(\mathrm{OR}=57.0,95 \% \mathrm{CI}: 1.9-\infty)$, yolk sac tumours $(\mathrm{OR}=11.1,95 \%$ CI: 1.6 -75.6), and other non-seminomas $(\mathrm{OR}=14.8,95 \% \mathrm{CI}: 1.5-$ 147.4). Cryptorchidism was not reported in any males with teratomas $(n=14)$ (data not shown).

\section{DISCUSSION}

In the largest case-control study of paediatric GCTs, we found limited evidence for an overall association between paediatric GCTs and Cas, with the exception of cryptorchidism. Other controlled studies have reported positive associations between paediatric GCTs and CAs, including any birth defect (Mann et al, 1993; Altmann et al, 1998; Bjorge et al, 2008), heart defects (Nishi et al, 2000), cryptorchidism (Nishi et al, 2000), and musculoskeletal/spinal abnormalities (Narod et al, 1997; Agha et al, 2005).

In males, there was an $\sim 11$-fold increased risk of GCTs in association with cryptorchidism, which is consistent with findings from adult testicular cancer studies (Sarma et al, 2006). Cryptorchidism in children with GCTs has been noted previously in case series and reports ( $\mathrm{Li}$ and Fraumeni, 1972; Huddart et al, 1990; Mukai et al, 1998) and in isolated cases in studies with comparison groups (Johnston et al, 1986; Wanderas et al, 1998). The excess risk in this study was primarily confined to gonadal tumours, with increased risks evident for seminomas, yolk-sac tumours, and other non-seminomas, which is consistent with what has been reported for adults (Coupland et al, 1999).

In females, there was no evidence of an association between CAs and GCTs. Reports of congenital ovarian abnormalities in association with ovarian GCTs are uncommon, with one case series study noting two cases of ovarian dysgenesis (Li et al, 1973); no such case was recorded in our study.

We observed an increased risk of extragonadal GCTs in individuals with reported skeletal defects, mental retardation, and congenital heart defects. Associations between skeletal and congenital heart defects and GCTs have been reported previously, but have not specified the tumour site (Narod et al, 1997; Nishi et al, 2000; Agha et al, 2005).

The strengths of this study include its relatively large size compared with that of previous studies and a more detailed analysis of previously reported associations. Limitations include $\mathrm{CA}$ ascertainment through a maternal interview that may be 
Table 3 The association between paediatric GCTs and congenital abnormalities by sex

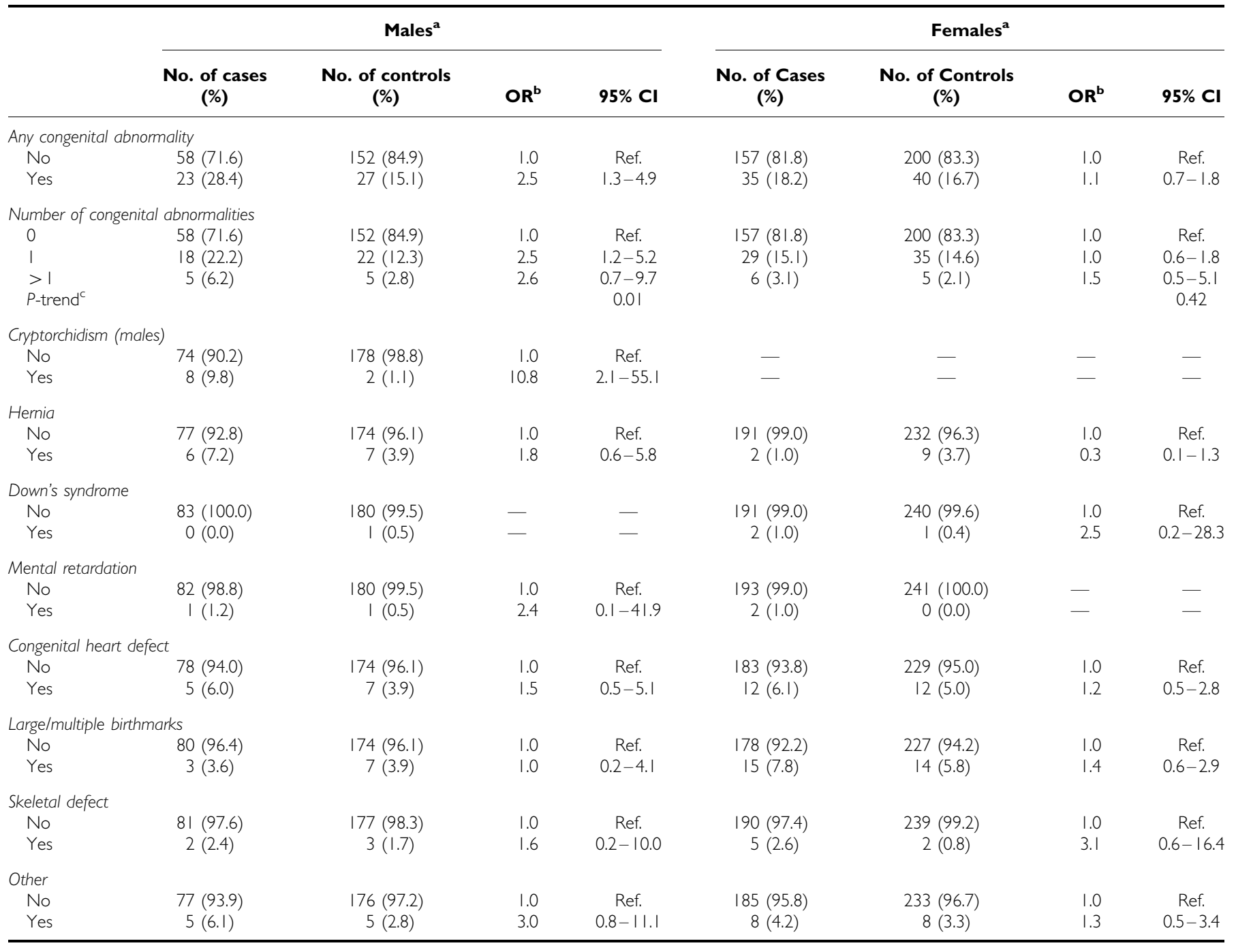

$\mathrm{CA}=$ congenital abnormality; $\mathrm{Cl}=$ confidence interval; $\mathrm{GCT}=$ germ cell tumour; $\mathrm{OR}=$ odds ratio. ${ }^{\mathrm{a}}$ Data were missing on at least one $\mathrm{CA}$ category in males for two cases and two controls and in females for three cases and one control. ${ }^{b}$ Adjusted for child's age (except for crytorchidism in which only males were included in the analysis). ${ }^{c}$ Calculated from model that included a continuous variable for the number of birth defects.

incomplete, especially for CAs that are minor or not clearly visible. The ascertainment of CAs may have been higher in cases because of the cancer investigations, which would produce a positive bias in the risk estimate (Rothman and Greenland, 1998). We were also limited by low statistical power to detect modest associations. Finally, selection bias may have affected our results if controls were not a representative of a sample of non-diseased individuals from the population from which cases were ascertained (Rothman and Greenland, 1998).

This study provides limited evidence for a link between most types of CAs and paediatric GCTs with the exception of cryptorchidism in males, and a possible link between certain types of CAs and extragonadal tumours.

\section{ACKNOWLEDGEMENTS}

We are grateful for the assistance of Dr Zhi Chen and Michelle Roesler in assembling the data set used for this study and for the retrieval of additional pertinent information from the study database that was not contained in the dataset.

This study was supported by NIH grants R01CA067263, U10 CA98413, U10 CA98543, and T32 CA099936, and the Children's Cancer Research Fund, Minneapolis, MN.

Supplementary Information accompanies the paper on British Journal of Cancer website (http://www.nature.com/bjc)

\section{REFERENCES}

Agha MM, Williams JI, Marrett L, To T, Zipursky A, Dodds L (2005) Congenital abnormalities and childhood cancer. Cancer 103: $1939-1948$
Altmann AE, Halliday JL, Giles GG (1998) Associations between congenital malformations and childhood cancer. A register-based case-control study. Br J Cancer 78: 1244-1249 
Bernstein LSM, Liu L, Deapen D, Friedman DL (1999) Germ cell, trophoblastic and other gonadal neoplasms. In Cancer Incidence and Survival among Children and Adolescents: United States SEER Program 1975-1995 Ries LAG, Smith MA, Gurney JG, Linet M, Tamra T, Young JL, Bunin GR (eds). National Cancer Institute, SEER Program. NIH Pub. No. 99-4649: Bethesda, MD, pp 125-138

Birch JM, Marsden HB, Swindell R (1982) Pre-natal factors in the origin of germ cell tumours of childhood. Carcinogenesis 3: 75-80

Bjorge T, Cnattingius S, Lie RT, Tretli S, Engeland A (2008) Cancer risk in children with birth defects and in their families: a population based cohort study of 5.2 million children from Norway and Sweden. Cancer Epidemiol Biomarkers Prev 17: 500-506

Chen Z, Stewart PA, Davies S, Giller R, Krailo M, Davis M, Robison L, Shu XO (2005) Parental occupational exposure to pesticides and childhood germ-cell tumors. Am J Epidemiol 162: 858-867

Coupland CA, Chilvers CE, Davey G, Pike MC, Oliver RT, Forman D (1999) Risk factors for testicular germ cell tumours by histological tumour type. United Kingdom Testicular Cancer Study Group. Br J Cancer 80: $1859-1863$

Fraumeni Jr JF, Li FP, Dalager N (1973) Teratomas in children: epidemiologic features. J Natl Cancer Inst 51: 1425-1430

Huddart SN, Mann JR, Gornall P, Pearson D, Barrett A, Raafat F, Barnes JM, Wallendsus KR (1990) The UK Children's Cancer Study Group: testicular malignant germ cell tumours 1979-1988. J Pediatr Surg 25: 406-410

Johnston HE, Mann JR, Williams J, Waterhouse JA, Birch JM, Cartwright RA, Draper GJ, Hartley AL, McKinney PA, Hopton PA (1986) The InterRegional, Epidemiological Study of Childhood Cancer (IRESCC): case-control study in children with germ cell tumours. Carcinogenesis 7: $717-722$

Li FP, Fraumeni JF (1972) Testicular cancers in children: epidemiologic characteristics. J Natl Cancer Inst 48: 1575-1581

Li FP, Fraumeni Jr JF, Dalager N (1973) Ovarian cancers in the young. Epidemiologic observations. Cancer 32: 969-972
Little J (1999) Epidemiology of Childhood Cancer 149 edn International Agency for Research on Cancer; Distributed by Oxford University Press: Lyon, Oxford

Mann JR, Dodd HE, Draper GJ, Waterhouse JA, Birch JM, Cartwright RA, Hartley AL, McKinney PA, Stiller CA (1993) Congenital abnormalities in children with cancer and their relatives: results from a case-control study (IRESCC). Br J Cancer 68: $357-363$

Merks JH, Caron HN, Hennekam RC (2005) High incidence of malformation syndromes in a series of 1,073 children with cancer. Am J Med Genet A 134: $132-143$

Mukai M, Takamatsu H, Noguchi H, Tahara H (1998) Intra-abdominal testis with mature teratoma. Pediatr Surg Int 13: 204-205

Narod SA, Hawkins MM, Robertson CM, Stiller CA (1997) Congenital anomalies and childhood cancer in Great Britain. Am J Hum Genet 60: $474-485$

Nishi M, Miyake H, Takeda T, Hatae Y (2000) Congenital malformations and childhood cancer. Med Pediatr Oncol 34: 250-254

Rankin J, Silf KA, Pearce MS, Parker L, Ward Platt M (2008) Congenital anomaly and childhood cancer: a population-based, record linkage study. Pediatr Blood Cancer 51: 608-612

Rothman KJ, Greenland S (1998) Precision and validity in epidemiologic studies. In Modern epidemiology 2nd edn, Rothma KJ, Greenland S (eds) pp 126. Lippincott-Raven: Philadelphia

Sarma AV, McLaughlin JC, Schottenfeld D (2006) Testicular cancer. In Cancer epidemiology and prevention 3rd edn, Schottenfeld D, Fraumeni JF (eds) pp 1159-1160. Oxford University Press: New York

US Census Bureau 2007 Population Estimates; generated by Kimberly J. Johnson; using American Fact Finder; <http://factfinder.census.gov $>$ (31 December 2008)

Wanderas EH, Grotmol T, Fossa SD, Tretli S (1998) Maternal health and pre- and perinatal characteristics in the etiology of testicular cancer: a prospective population- and register-based study on Norwegian males born between 1967 and 1995. Cancer Causes Control 9: 475-486 